\title{
THE STUDY OF CEPHALIC INDEX IN EASTERN ODISHA POPULATION
}

\author{
Ranjan Kumar Das ${ }^{1}$, Sujata Mohanty ${ }^{2}$
}

${ }_{1}^{1}$ Associate Professor, Department of Anatomy, PRM Medical College, Baripada, Odisha, India. ${ }^{2}$ Scientific Officer, Regional Forensics Science Laboratory, Berhampur, Odisha, India.

\author{
BACKGROUND \\ ABSTRACT \\ Morphology of all living beings undergo some changes during life. It is variable in individuals in same species. Referring the \\ various works on cephalic index and observing socioeconomical status of Eastern Odisha, this study was done to find out the \\ distribution of cephalic index in the population of Eastern Odisha.
}

\section{METHODS}

This cross-sectional study covered 2050 outdoor patients of Eastern Odisha which includes the costal districts of Odisha. Using spreading calipers maximum length and maximum breadth of the head were recorded. Cephalic Index= (Maximum Head Breadth/ Maximum Head Length)*100. Based on this calculated cephalic index, skulls are classified as Dolichocephaly, Mesocephalic, Brachycephalic and Hyper-brachycephalic.

\section{RESULTS}

From this present study, it was observed that mean cephalic index in females is higher than that of males. In males, maximum skulls were mesocephalic followed by dolichocephalic but in females, maximum were mesocephalic followed by brachycephalic. This study is in agreement with the study of Dr. Sunita Patro et al. e-ISSN:2279-0853, p-ISSN:2279-0861 vol. 13, Issue I, Ver VII (Jan, 2014) PP. 41-44 with a difference in measurements being on the higher side.

\section{CONCLUSIONS}

This may be accounted for social/nutritional influences on growth pattern. Dietary habit may also be a factor. This study is aimed to help surgery, FMT, Anatomy, Anthropology and the Study of Evolution.

HOW TO CITE THIS ARTICLE: Das RK, Mohanty S. The study of cephalic index in Eastern Odisha population. J. Evolution Med. Dent. Sci. 2019;8(13):965-968, DOI: 10.14260/jemds/2019/216

\section{BACKGROUND}

Changes are expected in all living beings on Morphology. In the same species also, changes may occur due to different factors like nutrition, culture, nature of work etc. ${ }^{14}$ Also, age and sex differences are marked.

Cephalometry is a simple procedure with less error and is very practical. The said index can be used as a tool for analysis of differences in individuals. This can be studied from information gathered from children and parents. ${ }^{2,10}$

Regarding the effect of geography, ethnicity and racial factors on head dimensions, the present study was aimed to elucidate the norms of cephalic indices ${ }^{3,1}$, the type of head shapes and sexual dimorphism in Eastern Odisha. Different dimensional measurements in anthropometry were taken into consideration and required calculations $6,8,9$ referring to the standard deviation in the system. The present study was done in Eastern Odisha population with reference to the study of Dr. Sunita Patro et. al. where they had conducted their study in another zone of the Odisha (Southern Odisha). $9,11,16$

'Financial or Other Competing Interest': None.

Submission 09-12-2018, Peer Review 01-02-2019,

Acceptance 09-02-2019, Published 01-04-2019.

Corresponding Author:

Dr. Ranjan Kumar Das,

Associate Professor, Department of Anatomy,

PRM Medical College, Baripada, Odisha, India.

E-mail: dr.ranjandas@yahoo.com

DOI: $10.14260 /$ jemds $/ 2019 / 216$

\section{METHODS}

\section{Year of Study}

2016.

\section{Study Design \\ Cross Sectional Study}

Samples were taken from 9 (nine) coastal districts of Eastern Odisha from where the patients and their accompanying relatives depended upon SCB Medical College and Hospital, Cuttack, Odisha. After obtaining consent from them, the due measurements were made. While taking measurements, some issues were noted early like deformities due to nutritional factors, genetic deformities, etc. Such cases were excluded from the present study. All the measurements were taken with the person sitting in the chair in relaxed condition and the head in the normal anatomical position. The method used for accessing cranial index was Hrdlick's Method. ${ }^{12}$ The maximum head length was measured as the maximum antero-posterior diameter by spreading calipers from glabella to irion. The maximum head breadth was measured as the maximum diameter between the two euryons using spreading calipers (electronic width sensitivity of $0.1 \mathrm{~mm}$ ).

All measurements were taken in millimeters to an accuracy of 0.1 fraction. The cephalic indices were calculated by multiplying the head breadth with 100 and dividing it by the head length. These indices express the type of head shapes which were classified as given by William's et. al., 1995.5 The variations have been reported to exhibit a clear 
racial or zonal trend. The strategically important points during osteometry procedures which would enlighten the neural or vascular complications that might arise after any surgery on head and neck. The relevant data on cephalic index of a population is very much essential in designing various orthopedic and physiotherapy equipment of head and face like cranial remodeling band (helmet), headphones, goggles etc. by formulating standard sizes.

In the present study, 2050 outdoor patients of SCB Medical College and Hospital, Cuttack were included. Age of the patients ranged from 20 to 60 years. Cases of accident affecting face or cranium, deformities of face and cases with some abnormalities in the head and neck were excluded.

\section{Key Words}

- Glabella- A point above the nasal root between the eye brows and vertically intersected by mid-sagittal plane.

- Inion- The distal most point placed on the external occipital protuberance in the mid-sagittal plane.

- Euryon- The lateral most point placed on the side of the head.

Classification done as given by Williams et al 1995.

\begin{tabular}{|c|c|c|}
\hline Sl. No. & Head Shape & Cephalic Index Range \\
\hline 1 & Dolichocephalic & $<75.0$ \\
\hline 2 & Mesocephalic & $75.0-79.9$ \\
\hline 3 & Brachycephalic & $80.0-84.9$ \\
\hline 4 & Hyperbrachycephalic & $85.0-89.9$ \\
\hline
\end{tabular}

\section{Statistical Analysis}

The data was analyzed by Microsoft Excel and all the statistical tests and the calculations were performed using the software GraphPad Prism Version 5. From the observations of the present study, the parametric data was analyzed using unpaired t-test (for two unmatched populations). ${ }^{20,21}$

\section{RESULTS}

SD - Standard Deviation, calculated for maximum head length (MHL), maximum head breadth (MHB) and Cephalic Index (CI).

\begin{tabular}{|c|c|c|c|c|c|}
\hline $\begin{array}{c}\text { Sl. } \\
\text { No. }\end{array}$ & \multirow{2}{*}{ Sex } & \multirow{2}{*}{ No. } & \multicolumn{3}{|c|}{ Mean \pm SD } \\
\cline { 4 - 6 } & & & MHL (in cm) & MHB (in cm) & C.I. \\
\hline 1 & Male & 1120 & $197.1 \pm 11.9$ & $152.1 \pm 9.7$ & $77.16 \pm 3.2$ \\
\hline 2 & Female & 930 & $192.0 \pm 16.0$ & $151.2 \pm 13.8$ & $78.79 \pm 3.40$ \\
\hline \multicolumn{3}{|c|}{ Table 1. Distribution of Male and Female } \\
\hline
\end{tabular}

\begin{tabular}{|c|c|c|c|c|c|c|}
\hline $\begin{array}{l}\dot{0} \\
\dot{z} \\
\dot{\omega}\end{array}$ & 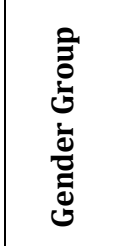 & 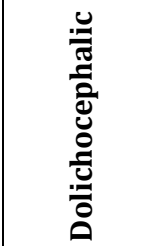 & 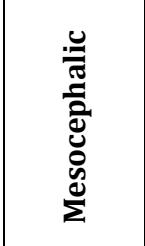 & 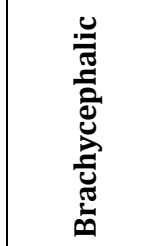 & 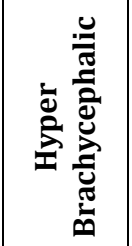 & $\begin{array}{l}\bar{\pi} \\
0 \\
0 \\
3 \\
0 \\
0 \\
0\end{array}$ \\
\hline 1 & Male & $\begin{array}{c}215 \\
(19.19 \%) \\
\end{array}$ & $\begin{array}{c}754 \\
(67.32 \%)\end{array}$ & $\begin{array}{c}130 \\
(11.60 \%)\end{array}$ & \begin{tabular}{|c|}
21 \\
$(1.87 \%)$
\end{tabular} & 1120 \\
\hline 2 & Female & $189(20 \%)$ & $\begin{array}{c}427 \\
(45.91 \%)\end{array}$ & $\begin{array}{c}296 \\
(31.83 \%)\end{array}$ & $\begin{array}{c}21 \\
(2.25 \%)\end{array}$ & 930 \\
\hline
\end{tabular}

The mean cephalic index of Eastern Odisha population was 77.89 with $\mathrm{SD} \pm 3.31$. Mean cephalic index for male was $77.16 \pm 3.25$ and for female it was $78.79 \pm 3.40$.

The Index difference was significant in male and female $(\mathrm{P}<0.001)$. The mean head length and breadth for male were 197.1 $\pm 11.4 \mathrm{~mm}$ and $152.1 \pm 9.3 \mathrm{~mm}$, for female $192.2 \pm 15.3$ and $151.2 \pm 13.8 \mathrm{~mm}$.

The difference was significant in head length $(\mathrm{P}<0.001)$ but insignificant in head breadth $(\mathrm{P}>0.05)$.
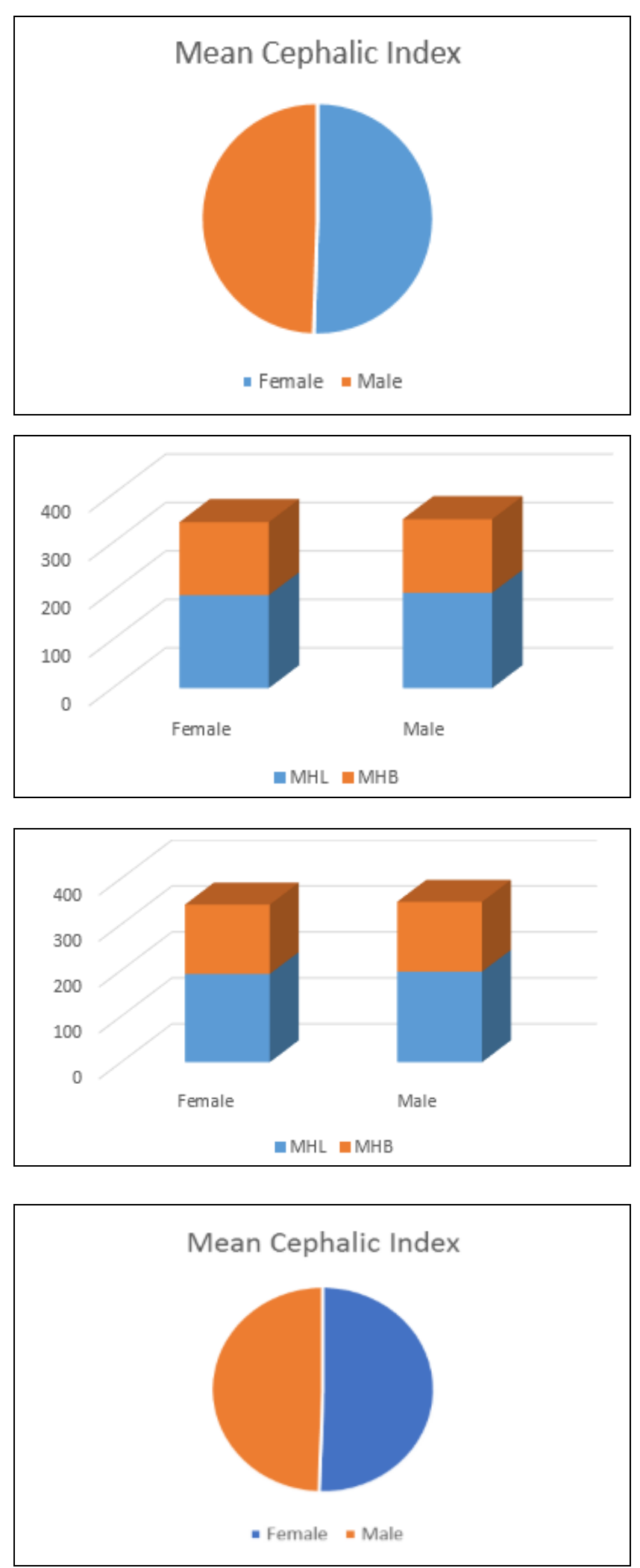


\section{DISCUSSION}

Study of cephalic index had been done by some workers as follows:

\begin{tabular}{|c|c|c|c|}
\hline $\begin{array}{l}\text { Sl. } \\
\text { No. }\end{array}$ & $\begin{array}{l}\text { Name of } \\
\text { Workers }\end{array}$ & $\begin{array}{c}\text { Population } \\
\text { Studied } \\
\end{array}$ & $\begin{array}{l}\text { Mean Cephalic } \\
\text { Index }\end{array}$ \\
\hline \multirow{2}{*}{1.} & \multirow{2}{*}{$\begin{array}{c}\text { Oladipo and } \\
\text { Olotu, 200615 }\end{array}$} & Ijaw Males & 80.98 \\
\hline & & Ijaw Females & 78.24 \\
\hline \multirow{2}{*}{2.} & \multirow{2}{*}{$\begin{array}{l}\text { Oladipo and } \\
\text { Olotu, 200615 }\end{array}$} & Igbo Males & 79.04 \\
\hline & & Igbo Females & 76.83 \\
\hline \multirow{2}{*}{3.} & \multirow{2}{*}{$\begin{array}{c}\text { Oladipo and } \\
\text { Olotu, 200915 }\end{array}$} & Ogonis Males & 111.18 \\
\hline & & Ogonis Females & 75.09 \\
\hline \multirow[b]{2}{*}{4.} & \multirow[b]{2}{*}{$\begin{array}{l}\text { Odokuma } \\
\text { et al, } 2010^{4}\end{array}$} & West African Males & 77.67 \\
\hline & & \begin{tabular}{|c|}
$\begin{array}{c}\text { West African } \\
\text { Females }\end{array}$ \\
\end{tabular} & 78.14 \\
\hline \multirow{2}{*}{5.} & \multirow{2}{*}{$\begin{array}{c}\text { Ilayperuma I, } \\
2011^{13}\end{array}$} & Srilankan Males & 78.04 \\
\hline & & Srilankan Females & 79.32 \\
\hline \multirow[b]{2}{*}{6.} & \multirow[b]{2}{*}{$\begin{array}{c}\text { Anitha } \\
\text { et al, } 2011^{19}\end{array}$} & North Indian Males & 79.14 \\
\hline & & \begin{tabular}{|c|}
$\begin{array}{c}\text { North Indian } \\
\text { Females }\end{array}$ \\
\end{tabular} & 80.74 \\
\hline \multirow{2}{*}{7.} & \multirow{2}{*}{$\begin{array}{l}\text { Yogain V K } \\
\text { et al, 201217 }\end{array}$} & $\begin{array}{c}\text { Indian Students } \\
\text { Males }\end{array}$ & 77.92 \\
\hline & & $\begin{array}{c}\text { Indian Students } \\
\text { Females }\end{array}$ & 80.85 \\
\hline \multirow{2}{*}{8.} & \multirow{2}{*}{$\begin{array}{l}\text { Mahesh Kumar } \\
\text { et al, } 2012^{18}\end{array}$} & Haryanvi Males & 66.72 \\
\hline & & Haryanvi Females & 72.25 \\
\hline \multirow{2}{*}{9.} & \multirow{2}{*}{$\begin{array}{c}\text { Ila Jitesh Gujaria } \\
\text { et al, } 2012^{20}\end{array}$} & Marathi Males & 77.08 \\
\hline & & Marathi Females & 79.02 \\
\hline \multirow{2}{*}{10.} & \multirow{2}{*}{$\begin{array}{c}\text { Ila Jitesh Gujaria } \\
\text { et al, } 2012^{20}\end{array}$} & Andhra Males & 76.28 \\
\hline & & Andhra Females & 78.16 \\
\hline \multirow{2}{*}{11.} & \multirow{2}{*}{$\begin{array}{c}\text { Ila Jitesh Gujaria } \\
\text { et al, } 2012^{20}\end{array}$} & Gujarati Males & 80.42 \\
\hline & & Gujarati Females & 81.20 \\
\hline \multirow[t]{2}{*}{12.} & \multirow{2}{*}{$\begin{array}{l}\text { PPatro Sumitra, et } \\
\text { al, 201416 }\end{array}$} & $\begin{array}{c}\text { Southern Odisha } \\
\text { Females }\end{array}$ & 77.28 \\
\hline & & $\begin{array}{l}\text { Southern Odisha } \\
\text { Females }\end{array}$ & 78.38 \\
\hline \multirow{2}{*}{13.} & \multirow{2}{*}{$\begin{array}{l}\text { Present study, } \\
2016\end{array}$} & $\begin{array}{c}\text { Eastern Odisha } \\
\text { Male }\end{array}$ & 77.16 \\
\hline & & $\begin{array}{l}\text { Eastern Odisha } \\
\text { Female }\end{array}$ & 78.79 \\
\hline
\end{tabular}

Our data shows that the cephalic index in our study population is closest to that of Marathi males and females.

1. Male dominated types - Mesocephalic $67.32 \%$.

2. Female dominant type - Mesocephalic $45.91 \%$.

\section{Followed by}

- Male- Dolichocephalic, Brachycephalic and Hyperbrachycephalic.

- Female- Brachycephalic, Dolichocephalic and Hyperbrachycephalic

in that order. Differences observed in different studies may be due to genetic, nutritional, and socioeconomic factors.

\section{CONCLUSIONS}

The cephalic index in our study population is closest to that of Marathi males and females. Further study with larger sample is needed. Food habits and socio-economy need to be corelated. A genetic study is also needed.

\section{REFERENCES}

[1] Golalipur et al. The shapes of head and face in normal female newborns in south-east of Caspian Sea (IranGorgan). Eur. Jr. Anat. 2005;9(2):95-98.
[2] Imami-Mibodi MA and Mastri-Frahani R. Study of normal range of anatomical dimensions of one-day old newborn by cephalometry. J Med Council Islamic Republic of Iran.1996; 14: 1-8.

[3] Del Sol M. Cephalic index in a group of mapuche individuals in the IX Region of Chile. Int. Jr. Morphology, 2005; 23(3):241-246.

[4] Oladipo GS, Olotu JE and Suleiman Y. Anthropometric studies of Cephalic indices of the Ogonis in Nigeria. Asian Journal of Medical Sciences. 2009; 1(2):15-17.

[5] William P, Dyson M, DussaakJ E, Bannister LH, Berry MM, Collins P, Ferguson MWJ. Gray's Anatomy. In: Skeletal system, 38th Edn. Elbs with Churchil Livingston, London, (1995). p 607-612

[6] Agron Rexhepi and Vjollca Meka. Cephalofacial morphological characteristics of Albanian Kosova population. Int. Jr. of morphology, 2008; 26(4):935940.

[7] Odokuma, E.I., Akpuaka, F. C., Igbigbi, P. S., Otuaga, P.O. and Ejebe, D. Patterns of cephalic indices in three West African population. African Journal of Biotechnology.2010; 9(11):1658-1662.

[8] Grant TM and Peter AM. Size and shape measurement in contemporary cephalometrics. Eur. Jr. of Orthodontics, 2003; 25(3):231- 242.

[9] Shah GV, Jadhav HR.The study of cephalic index in students of Gujrat. J Anat Soc India. 2004; 53(1):1-12. Rabey GP. Craniofacial morphoanalysis. Proc. R. Soc. Med. 1971; 64:103-111.

[10] Afak SY and Turgut HB. Weight, length.head and face measurements in Turkish newborns of central Anatolia. Gaji Medical Journal.1998;9: 116-120.

[11] Singh P, Purkit R. A cephalometric study among subcaste groups Dangi and Ahirwar of Khurai Block. Anthropol. 2006: 8(3): 215- 17.

[12] Hrdlika Practical Anthropometry. 4th Edition, Philadelphia. The Wistar institute of Anatomy and Biology, 1952:87-89.

[13] Ilayperuma I. Evaluation of cephalic indices of Srilankan population: A clue for Racial and Sex diversity. Int. Jr. Morphol. 2011; 29(1):112-117.

[14] Eickstedt E.V. The races and types of the western Himalayas. Map in India. 1926; 6: 237.

[15] Oladipo, G.S. and E.J. Olotu. Anthropometric comparison of cephalic indices between the ijaw and igbo tribes. Global Jr. Pure appl. Sci., 2006; 12(1):137138.

[16] Patro Sumitra, Sahu Ramakrishna and Rath Sadananda, Study of Cephalic Index in Southern Odisha Population in IOSR Journal of Dental and Medical Sciences. 2014; Vol. 13, 1(7):41-44.

[17] Yogain VK, Pai SR, Kalthur SG, Hemalatha I. Study of Cephalic index in Indian students. Int. Jr. Morphol. 2012; 30(1):125-129.

[18] Kumar M. and Patnaik V.V. Gopichand. The study of cephalic index in Haryanvi population. Int. Jr. of Pure and Appl. Biosc. 2013; 1(3): 1-6.

[19] Anitha. M.R, Vijayanath. V, Raju.G.M, Vijayamahantesh S.N. Cephalic Index of North Indian Population. Anatomica Karnataka. 2011; 5(1):40-43. 
[20] Gujaria IJ, Salve VM. Comparison of Cephalic index of three states of India. Int. Jr. Pharma. Bio. Sci. 2012;3(4):1022-1031.
[21] Mahajan BK. Textbook of biostatistics. 7th Edition. 2012. 